\title{
Örgütsel Vatandaşlık Davranışında Kontrol Odağı, Örgütsel Adalet Algısı ve Örgütsel Bağlılığın Etkisi
}

\author{
The Effects of Locus of Control, Organizational Justice Perception and \\ Organizational Commitment on Organizational Citizenship Behavior
}

\author{
Doç. Dr. Cem Harun Meydan - Prof. Dr. H. Nejat Basım
}

\section{Öz}

Örgüt içinde birey davranışlarını biçimleyen farklı bireysel ve örgütsel faktörler, örgütü yıkıcı ve istenmeyen davranışlardan koruyarak, örgütün performansını ve verimliliğini artırıcı etkiler yaratabilmekte olan Örgütsel Vatandaşlık Davranışları (ÖVD) üzerinde etkili olabilmektedir. Bu çalı̧̧mada, anılan faktörlerden, bireysel bir nitelikte olan kontrol odağı ile örgütsel faktörlerden olan adalet algisı ve bağhlliğın ÖVD üzerindeki etkileri bütüncül bir bakış açısı ile ele alınmaktadır. Bu maksatla 232 alt ve orta kademe kamu yöneticisinden veri toplanmış ve analizler bir yapısal eşitlik modeli çerçevesinde yürütülmüşü̈r. Elde edilen bulgular, çalışmada ele alınan değişkenler arasındaki ikili ilişkileri inceleyen önceki çalışmaların bulgularını desteklemektedir. Ayrıca değiş̧kenler arasındaki ilişkiler bir bütün olarak ele alındiğında, kontrol odağı, adalet algısı ve bağllhğın ÖVD üzerindeki etkileri ortaya konulmuş; bunun yanı sıra, kontrol odağı-ÖVD ilişkisinde adalet algısının aracıllk etkisinin olduğu belirlenmiștir.

Anahtar Kelimeler: Örgütsel Vatandaşlık Davranışı, Kontrol Odağı, Örgütsel Adalet, Örgütsel Bağlllık

\begin{abstract}
Personal and organizational factors, which have effect on personal behaviors, can increase organizational performance and effectiveness by protecting the organization from unwanted behaviors and can have an effect on Organizational Citizenship Behaviors (OCB).
\end{abstract}

In this study, locus of control (LOC) has been included to the research as a personal variable and organizational justice perception and organizational commitment have been included to the research as organizational variables to put forth their effects on OCB on a holistic approach. The data was gathered from 232 public managers and analyzed with structural equation modeling approach. The findings support the findings of the previous studies, which investigated two sided relationships between the variables. Besides these findings, taken the relationships among the variables as a whole, LOC, organizational justice and organizational commitment have direct effects on $O C B$ and organizational justice has a mediating effect between LOC and OCB.

Keywords: Organizational Citizenship Behavior, Locus of Control, Organizational Justice, Organizational Commitment

\section{Giriş}

Günümüzde, örgütlerin yönetsel etkililiğini ve verimliliğini artırmaya yönelik olarak yapılan araştırmaların büyük çoğunluğu, çalışan davranışlarının anlaşılması, temellendirilmesi ve yönlendirilmesine yönelik olmaktadır. Bu kapsamda Endüstri ve Örgüt Psikolojisi ile Örgütsel Davranış odaklı çalışmaların üzerine yoğunlaştığı konulardan birisi de Örgütsel Vatandaşlık Davranıșları (ÖVD)'dır. Çalıșanların, biçimsel rollerinin ötesinde, herhangi bir emir ya da

Doç. Dr. Cem Harun Meydan, Kara Kuvvetleri Komutanlı̆̆ı, chmeydan@gmail.com Prof. Dr. H. Nejat Basım, Başkent Üniversitesi İIBF, nbasim@baskent.edu.tr 
talimata dayalı olmadan sergiledikleri, örgüte katkı sağlayan davranışlar olarak tanımlanan örgütsel vatandaşlık davranışları, örgütü yıkıcı ve istenmeyen davranışlardan koruyarak, örgütün performansını ve verimliliğini artırıcı etkiler yaratabilmektedir (Organ, 1988).

Örgüt içinde birey davranışları üzerinde etkili olan farklı örgütsel faktörler bulunduğundan, ÖVD'nin de söz konusu faktörlerden etkilenmesi söz konusu olmakta; buradan hareketle, hem konuya yönelik kurama katkı hem de etkili uygulamalar açısından, çalışan bireylerin örgütsel vatandaşlık davranışı göstermelerini etkileyebilecek faktörlerin ortaya çıarılması büyük önem arz etmektedir.

Bu bağlamda çalışmanın amacı, bireysel bir faktör olarak kontrol odağını, örgütsel faktörler olarak da örgütsel adalet algisı ve örgütsel bağlılığ ele alarak, bu faktörlerin ÖVD üzerindeki öncüllük rolünü ortaya koymaktır.

Araştırma yukarıda sıralanan bireysel ve örgütsel faktörlerin bir arada ele alındığ bir yapısal eşitlik modeli üzerinden örgütsel davranışın bir yönünü anlamaya ve açıklamaya çalışmaktadır. Bu maksatla, oluşturulan model, bu değişkenler arasındaki ikili ilişkilerden oluşan bir kuramsal bir yapı üzerine geliştirilmiştir. $\mathrm{Bu}$ model üzerinde kontrol odağı bağımsız, ÖVD bağımlı, örgütsel adalet algısı ve örgütsel bağlılık ise hem bağımlı hem de bağımsız değişkenler olarak ele alınmaktadır. Bu çerçevede çalıșmamızda öncelikle araştırmamızın bağımlı değişkeni olan ÖVD, ardından bağımsız değişken olan kontrol odağı ele alınarak, ÖVD - Kontrol odağı ilişkisi ortaya konulmaktadır. Daha sonra, örgütsel değişkenler olan adalet algıs1, ÖVD ve kontrol odağı ile ilişkilendirilerek ele alınmaktadır. Son olarak örgütsel bağllık ve bu değişkenin diğer değişkenlerle ilişkisi ortaya konularak yapısal modelin kuramsal çerçevesi oluşturulmaktadır.

\section{Kuramsal Çerçeve}

\section{Örgütsel Vatandaşlık Davranışı}

Biçimsel ödül sistemini dikkate almaksızın, bir bütün olarak örgütsel fonksiyonların verimli ve etkili biçimde yerine getirilmesine yardımcı olan, gönüllülük esasına dayalı birey davranışı olarak ele alınan ÖVD (Bateman ve Organ, 1983; Organ, 1988; Smith vd.,
1983), aynı zamanda, görev ve iş tanımlarında zorunlu tutulmayan, ihmali halinde ceza gerektirmeyen ve daha çok kişisel tercih sonucu sergilenen davranışlar olarak da nitelenmektedir (Podsakoff vd. 2000). Yazında ÖVD' ye yönelik olarak 'Prososyal Örgütsel Davranış" (Brief ve Motowidlo, 1986; McNeely ve Meglino, 1994), "Ekstra Rol Davranışı" (Van Dyne vd., 1994), "İyi Asker Sendromu” (Organ, 1988; Turnipseed ve Murkison, 1996; 2000), "Bağlamsal Performans" (Van Scotter ve Motowidlo, 1996) biçiminde farklı adlandırmalar da yapıldığı görülmektedir.

ÖVD'nin boyutları konusunda da benzer bir farkl1laşma göze çarpmaktadır. Bir çalışmada (Podsakoff ve ark., 2000) 30 farklı vatandaşlık davranışı tanımlanırken; başka bir çalışmada (Smith ve ark., 1983) "diğerkâmllk" ve "genelleștirilmiş uyum" olmak üzere iki faktör tanımlanmaktadır. Farklı bir çalışmada (Organ, 1988) ise ekstra rol davranışı tanımı geliştirilerek örgütsel vatandaşlık davranışı kavramı ortaya konmuş ve beş boyutlu bir yapı önerilmiştir. Yazında genel kabul görmüş olan bu yapı içindeki boyutlar; diğerkâmlık, nezaket, vicdanlılık, sivil erdem ve centilmenlik olarak isimlendirilmektedir.

Diğerkâmlık (özgecilik), diğer kişilere yardım etmeye veya işle ilişkili sorunların ortaya çıkmasını önlemeye yönelik gönüllü davranışları içermektedir (Organ ve Konovsky, 1989; George ve Jones, 1997; Podskoff vd., 2000). Vicdanlılık, çalışanların kendilerinden beklenen asgari rol davranışının ötesinde bir rol davranışını gönüllü olarak sergilemelerini ifade etmektedir (Organ, 1988). Nezaket, başkalarının işlerini etkileyecek hareketler yapmadan veya kararlar almadan önce onları bilgilendirmeye dayanan davranışları ifade ederken (Deluga, 1995); sivil erdem davranışı da örgütü etkileyen olaylara karşı çalışanların kendilerini sorumlu kılmaları ve kararlara sorumlu ve gönüllü bir şekilde katılmaları olmaktadır (Schnake ve Dumler, 1993). Centilmenlik ise işe ilişkin kaçınılmaz sorunları veya zorlukları şikayet etmeden kabul etme istekliliği olarak tanımlanabilmektedir (Podsakoff vd., 2000).

Son dönemdeki çalışmalarda, ÖVD’nin yukarıda ifade edilen beş boyutlu yapısı iki ayrı grupta toplanarak “Kişiye Yönelik ÖVD” ve "Örgüte Yönelik ÖVD” olarak adlandırılmıştır (DiPaola ve Tschannen-Moran, 2001; Lepine vd., 2002; Moon vd., 2005; Williams ve Anderson, 1991). Bu çerçevede diğerkâmlık ve nezaketin kişiye yönelik; vicdanlılık, sivil erdem ve centilmenliğin ise örgüte yönelik ÖVD’leri kapsadığı ifade 
edilmektedir (Deluga, 1995; George ve Jones, 1997; Organ ve Konovsky, 1989; Podsakoff vd., 2000; Williams, 1988; Williams ve Anderson, 1991).

Bireyler, içinde bulundukları örgüt ile uyumları arttıkça ÖVD gösterme eğiliminde olmakta; ancak, birey-örgüt uyumu ÖVD’ye dolaylı olarak etki etmektedir (Sua'rez-Mendoza ve Zoghbi-Manrique-de-Lara, 2007). Bu dolaylı etki örgütsel bağlllık, iş tatmini ya da örgütsel adalet gibi farklı örgütsel değişkenler üzerinden gerçekleşebilmektedir (Verquer vd., 2003). Bununla birlikte kişilik değişkenleri birey-örgüt uyumu üzerinde etkili olabilmektedir (Chatman, 1989). Bu nedenle, ÖVD ile ilgili yapılmış olan çalışmalarda, ÖVD’nin öncüllerinin kişilik özellikleri gibi bireysel; görev özellikleri, örgütsel ortam ve liderlik davranışları gibi örgütsel faktörler etrafında toplandığı görülmektedir (Podsakoff vd., 2000). Bazı çalışmalarda, kişilik özelliklerinden kontrol odağı, proaktif kişilik ve öz güvenin ÖVD'yi etkilediği ortaya konulmuştur (Li vd., 2010; Van Dyne vd., 2000).

\section{Kontrol Odağı}

ÖVD’nin bireysel bağlamda bir öncülü olarak çalı̧̧mamızda ele aldığımız kontrol odağı, bireylerin yaşadıkları olayları nelerin kontrol ettiğine dair inancı olup, yaşadıkları pekiştirmelerin, yani elde ettikleri sonuçların veya ödüllerin, ya da başarı veya başarısızlık durumlarının, nelere atfedildiği ile ilişkilidir (Bush, 1988; Rothbaum vd., 1982; Strauser vd., 2002).

İnsanlar, başlarına gelen iyi ve kötü olayların sebeplerini algılama bakımından farklılaşmakta; bu farklılık, insanların hem kendileriyle ilgili hem de başkalarının yaşadığı durumları algılama ve değerlendirmelerinde de farklılaşmaya neden olmaktadır (Rotter, 1966; Taylor vd., 2006). Bazı kişiler, davranışlar ile pekiştireçler arasında bir ilişkinin olduğunu varsayarak, pekiştireçlerin kendi davranışları tarafından kontrol edildiğini düşünürken; diğerleri bu ilişkinin olmadığını, pekiştireçlerin kendisi dışında bir güç tarafından kontrol edildiğini düşünmektedir. Davranışları ile pekiştireçleri arasında bir ilişki olduğunu düşünen kişiler iç kontrol odaklı olarak tanımlanırken; böyle bir ilişkinin olmadığını düşünenler dış kontrol odaklı olarak tanımlanmaktadır (Oliver vd., 1954; Twenge vd., 2004).

İç kontrol odaklıların, dış kontrol adaklılara nazaran daha başarıll, etkili, atılgan, girişimci, güvenli ve bağımsız kişiler oldukları (Bernardi, 2001; Loosemore ve Lam, 2004; Libert vd., 2003; Silvester vd., 2002; Yeşilyaprak, 2000); akademik nitelikli ve yarışma ortamlarında daha üstün sonuçlar elde ettikleri ve toplumsal olaylarda daha aktif roller aldıkları (Anderson vd., 2005; Diesterhaft ve Gerken, 1983; Yağışan vd., 2007); kendilerini daha sağlıklı hissettikleri (Ozolins ve Stenstrom, 2003); başa çıma becerilerinin daha yüksek olduğu (Elise vd., 1998) ve içsel motivasyonlarının daha fazla olduğu (Fazey ve Fazey, 2001) belirtilmektedir.

İç kontrol odaklı bireyler daha fazla prososyal davranış gösterme eğilimindedirler (Hoffi-Hofstetter ve Mannheim, 1999). Bu bireyler standartlaştırılmış rol davranışları içine hapsolmak istemeyerek kontrolü ellerinde bulundurmaya çalışmaktadırlar (Blakely vd., 2005). Dolayısıyla, iç kontrol odaklılar, davranışlarının farklılık yaratacağı inancı ile hareketlerinin sorumluluğunu yüklenerek, işe yönelik olarak ve iş gereklerinin haricinde, daha fazla davranış sergilemektedirler (Withey ve Cooper, 1989). Sonuç olarak örgütsel vatandaşlık davranışlarının iç kontrol odağı ile ilişkili olduğu görülmektedir (Hoffi-Hofstetter ve Mannheim, 1999; Spector ve Fox, 2003).

Kontrol odağı ve örgütsel vatandaşlık davranışları ile ilgili ilişkiler ve kuramsal çerçeve içinde sıralanan sonuçlar, iç kontrol odaklı olmanın olumlu bir kişilik özelliği olduğu kanısını vurgulamakta (Loosemore ve Lam, 2004; Malki, 1998; Silvester vd., 2002) ve iç kontrol odağı eğiliminin çalışma ortamında örgütsel vatandaşlık davranışlarını ortaya çıkarabileceğini göstermektedir (Basım ve Şeşen, 2006a; Withey ve Cooper, 1989). Bu kuramsal gerekçeler çerçevesinde aşağıdaki hipotez oluşturulmuştur:

\section{Hipotez 1. İç kontrol odaklı bireyler daha fazla örgütsel vatandaşlik davranışları sergilerler.}

OVD’nin başka bir nedeni de durumsal faktörlerdir. $\mathrm{Bu}$ durumsal faktörler, örgütsel değişkenler bağlamında, iş tatmini, dürüstlük algısı, örgütsel bağll1lk, örgütsel adalet algısı ve algılanan lider desteği olarak örneklenebilecek değişkenlerin etkisi altında ortaya çıkabilmekte olup, bu konuda yapilmış olan araştırmaların bulguları ÖVD'nin bu özelliklerle az ya da çok ilişkili olduğunu ortaya koymaktadır (Bateman ve Organ, 1983; O’Reilly ve Chatman, 1986; Organ ve Ryan, 1995; Smith vd., 1983). Bu değişkenlerden, bireylerin örgüt içi davranışları üzerinde etkisi ve önemine vurgu yapılan örgütsel adalet algısı (Hartman 
vd., 1999), ÖVD’nin en güçlü öncüllerinden birisidir (Podsakoff vd., 2000). Bunun yanı sıra, örgütsel bağlılık da bireylerin örgüte yönelik tepkilerinin önemli bir göstergesi olarak ifade edilebilir (Ng vd., 2006). $\mathrm{Bu}$ bağlamda değerlendirildiğinde, çalışanların adalet algıları ve örgütsel bağlılıkları, örgütsel faktörler kapsamında ÖVD’nin önemli öncülleri olarak göze çarpmaktadır.

\section{Örgütsel Adalet Algısı}

Çalışmamızda ele alınan örgütsel değişkenlerden $a d a$ let algısı, bireylerin örgüt içinde kendilerine karşı adil olunup olunmadığ buna göre tutum geliştirmelerini sağlamaktadır (Greenberg, 1990). Örgütsel adalet konusunda araştırmaya dayalı bilginin, zaman içinde, birbirini izleyen çalışmalar ile aşama aşama geliştirildiği görülmektedir (Ambrose, 2002; Bies ve Moag, 1986; CohenCharash ve Spector, 2001; Colquitt, 2001; Greenberg, 1990;1993; Nowakovski ve Conlon, 2005; Thibaut ve Walker, 1975). Anılan çalışmalar değişik bakış açılarıyla yapılmış ve bu çalışmalar örgütsel adaletin, bölüşümsel adalet, süreç adaleti ve etkileşim adaleti olarak ifade edilen boyutlarını ortaya koymuştur.

Bölüşümsel adalet, bir çalışanın, işe yaptığı katkılar ve bu katkılar sonucunda karşılaştığ 1 ödül, görev, sorumluluklar gibi iş ile ilgili sonuçları, diğer çalışanların katkı dereceleri ve karşılaştıkları sonuçlar ile karşılaştırması sonucunda algıladığı adalettir (Andersson-Stråberg, vd., 2007; Greenberg, 1990). Çalışanlar tarafından karşılaşılan sonuçların adil dağılmış olması bu algıyı oluşturmaktadır. Bölüşümsel adalet, örgütte otoritenin değerlendirilmesi, iş tatmini, örgütsel bağlllık ve güven gibi çalışanların örgüt içi tutum ve davranışlarıyla doğrudan ilişkilidir (Colquitt vd., 2001). Süreç adaleti kararlara ulaşmada kullanılan süreçlerin adilliği olarak tanımlanmakta, yönetici tarafından verilen bir kararın, sonucu ne olursa olsun, kontrollü bir süreç sonunda alındığ takdirde, adil olarak algılandığını ifade etmektedir (Ambrose, 2002; Irak, 2004; Nowakovski ve Conlon, 2005; Thibaut ve Walker, 1975). Etkileşim adaleti ise, adalet çalışmalarının sosyal yönünü oluşturmakta ve bireyler arasındaki ilişkinin kalitesine işaret etmektedir (Ambrose, 2002). Etkileşim adaleti, çalışanların örgüt içinde karar vericilerin kendilerine karşı tavırlarının ve örgüt içinde alınan kararlar ile ilgili yapılan açıklamaların bireylerin adalet algılamalarını etkilediğini ifade etmektedir (İşbaşı, 2001).
Kişilik değişkenleri örgütsel adalet algısı üzerinde etkili olabilmektedir (Brennan ve Skarlicki, 2004; Shi vd., 2009; Zimmerman, 2008). Bir kişilik değişkeni olan kontrol odağı ve adalet algısı ilişkisi dikkate alındığında, iç kontrol odağı eğilimli bireylerin adalet algılamalarının yüksek olabildiği görülmektedir (Youn, 2007). İç kontrol odaklı bireylerin daha fazla bağlılık (Coleman vd., 1999), tatmin (Spector, 1988) ve ÖVD (Withey ve Cooper, 1989) sergilediği, aynı zamanda adalet algısındaki artışın da, benzer şekilde örgütsel bağlılık, iş tatmini ve örgütsel vatandaşlık davranışını etkileyebildiği (Colquitt vd., 2001) dikkate alındığında; iç kontrol odaklı bireylerin örgüt içinde yüksek adalet algısına sahip olması beklenebilir.

Bununla beraber, iç kontrol odaklı bireylerin, örgütteki kazanımların dağıtımı ve süreçler ile ilgili karşılaşılan durumları, kendi davranışlarının bir sonucu olarak görmeleri mümkündür. $\mathrm{Bu}$ nedenle, örgüt içindeki adalet ile ilgili durumların da kendilerinden kaynaklandığını düşünmeleri ve bunun sonucunda adaletsizlik hissetmemeleri beklenebilir. Bu kuramsal gerekçelerden yola çıkarak aşağıdaki hipotez oluşturulmuştur:

Hipotez 2. İç kontrol odaklı bireylerin, örgüt içinde algıladikları adalet daha yüksektir.

Bireylerin örgüt içinde adaleti önemsemesi (Folger, 1998), örgütsel adalet algısını bireylerin örgüt içindeki davranışlarını şekillendiren unsurlardan biri ( $\mathrm{Na}-$ surdin ve Khuan, 2007) haline getirmekte ve adalet algısındaki artış ya da azalma, iş tatmini, performans, örgütsel vatandaşlık davranışı ve iş gücü devrini etkileyebilmektedir (Colquitt vd., 2001). Bunun bir sonucu olarak adalet algısı, bireylerin örgüte bağlılığını (Folger ve Konovsky, 1989), örgütsel vatandaşlık davranışı göstermesini (Niehoff ve Moorman, 1993; Moorman, 1991; Moorman vd., 1993), iş tatminini, geri çekilme davranışını, örgütle özdeşleşmesini ve örgüte duyulan güvenini etkileyebilmektedir (Ambrose, 2002; Cohen-Charash ve Spector, 2001; Lee, 2001; Viswesvaran ve Ones, 2002; Zhang, 2006).

Adalet algısı ve ÖVD ilişkisini ortaya koymak için yapılmış olan çalışmalar (Niehoff ve Moorman, 1993; Moorman, 1991; Moorman vd., 1993), adalet alg1s1nın ÖVD’nin en güçlü öncüllerinden biri olduğunu ortaya koymakta (Podskoff vd., 2000) ve diğer çevresel faktörler arasında göreceli önemini vurgulamaktadır (O'Brien, 2004). 
Özellikle, örgütsel vatandaşlık davranışını güdüleyen faktörlerin incelendiği çalışmalarda, en çok vurgulanan bilișsel faktörün, çalışanların adalete ilişkin algılamaları olduğu (Moorman, 1991; Organ, 1998; 1990) görülmektedir. Yöneticilerinden adil muamele gördüklerine inanan çalışanların daha fazla örgütsel vatandaşlık davranışları sergilediklerinden (Moorman, 1991) yola çıkılarak, bireylerin örgütsel vatandaşlık davranışı gösterdiği yerlerde örgütsel adalet algıladıkları ifade edilmektedir (Ortiz, 2000).

Bununla birlikte, çalışanlara gösterilen muamelenin örgütsel açıdan gerekli davranışların sergilenmesinde önemli olabildiği belirtilmekte (Konovsky ve Pugh, 1994) ve böylelikle etkileşim adaletinin önemine de vurgu yapılmaktadır. Adalet algilamalarının olumlu etkisinin aksine, bireyler adaletsizlik algıladıkları zaman, üretim hızını ve kalitesini düşürmek yerine örgütsel vatandaşlık davranışları gibi gönüllülüğe dayalı davranışlarını azaltma ya da saklama eğilimi gösterebilmektedirler (İşbaşı, 2000). Bireylerin örgütsel vatandaşlık davranışlarından vazgeçme nedeninin, örgütsel adaletsizliği algılayan bireyin, biçimsel iş tanımı gereklerine uymadığ takdirde biçimsel ödüllerden mahrum kalabileceğini bilmesi olarak ifade edilmektedir (İşbaşı, 2000; Moorman, 1991; Organ, 1998). Ayrıca, bireylerin vatandaşlık davranışları göstermelerine neden olan faktörlerden bir diğeri de, bireylerin yöneticileri hakkında dürüst ve adil davrandıkları şeklindeki değerlendirmeleri ve buna karşılık verme düşüncesi olmaktadır (İşbaşı, 2000; Organ ve Moorman, 1993). Bu gerekçeler ışığında aşağıdaki hipotez oluşturulmuştur:

Hipotez 3. Örgüt içinde bireylerin algıladiğı adalet, örgütsel vatandaşlık davranışları üzerinde etkilidir.

\section{Örgütsel Bağlılık}

Çalışmamızda bir diğer örgütsel değişken olarak örgütsel bağlllık konusuna odaklanılmıştır. Zira bireyler örgütlerine bağlı oldukları zaman da örgütleri lehine, görev tanımlarında olmayan davranışlar göstermektedir (Meyer ve Herscovitch, 2001). Örgütsel bağl1lık, kişinin, örgüt özelliklerini içselleştirmesi, örgütsel bakış açısına uyum gösterme derecesi (O'Reilly ve Chatman, 1986), örgütün hedef ve değerlerinin elde edilmesine katkıda bulunan bir unsur olarak görmesi (DeCotiis ve Summers, 1987); örgütsel hedef ve çıarları karşılayacak şekilde davranmayı sağlayan içselleştirilmiş normatif baskılar (Wiener, 1982) ana noktalarına dayandırılmaktadır. Bazı tanımlar bu kavramın, kişinin davranıșları tarafından sınırlanma durumunu ve bu davranıșları vasıtasıyla bağlılı̆̆ını devam ettirme inancını (Salancik, 1977) ya da kişilerin örgütleri ile özdeşleşme derecelerinin ve örgütleri ile oluşturdukları bağın kuvvetini (Porter vd., 1974; Steers, 1977) ifade ettiğini belirtmektedir.

Örgütsel bağlılık ile ilgili farklı boyutlandırmalar olmakla beraber, yazında genel kabul görmüş olan boyutlandırmanın Allen ve Meyer'in (1990) siniflandırması olduğu görülmektedir. Bu boyutlar duygusal bağlllık, devam bağlılı̆ğ ve normatif (ahlâki) bağgl1liktır.

Duygusal bağllılk, benzer değerler taşımaktan kaynaklanan olumlu etkiye dayalı olan bir bağlılık türüdür ve bireyin örgütle özdeşleşmesini, örgüte duygusal açıdan bağlanmasını ve ilgi göstermesini içermektedir (Allen ve Meyer, 1990; Meyer ve Allen, 1997; Meyer vd., 2002). Devam bağhllı̆g, örgütten ayrılmanın maliyetinin çok yükssek oluşuna ya da başka bir alternatif olmayışına bağlı olup (Meyer vd., 2002) çalışanların örgütte kalmaya ihtiyaç duymaları sonucu gelişmektedir. Normatif bağhllı̆a sahip kişiler ise sorumluluk ve ahlâki bir yükümlülük duygusu ile "zorunluluk hissettikleri için" örgütlerine bağlanmakta; örgütleri için iyi olanı yapma motivasyonu taşımaktadırlar ve uygun iş davranışları göstermeye isteklidirler (Meyer ve Allen 1991).

Kişilik değişkenleri örgütsel bağll1lk üzerinde de etkili olabilmekte ve kontrol odağı eğilimi bireylerin örgüte olan bağlılıklarını etkileyebilmektedir (Coleman vd., 1999; Hollenbeck vd., 1989). Araștırmalar iç kontrol odaklı bireylerin, daha fazla iş doyumu, işe bağlllık ve motivasyon sahibi olduklarını göstermektedir (Munir ve Sajid, 2010; Wang ve Chen, 2007). Bu durumla ilişkili olarak, iç kontrol odaklı bireylerin, ayrıca, başarısızlıkları ile ilgili, kendilerine ve kontrol edilebilir davranışlara atıfta bulunan bireylerin, işte daha fazla gelişim kaydettikleri ve yüksek iş motivasyonuna sahip oldukları da belirtilmektedirler (Silvester vd., 2002). Bu kuramsal gerekçeler çerçevesinde aşağıdaki hipotez oluşturulmuştur:

Hipotez 4: İç kontrol odakl bireylerin, örgüte bağlllık seviyeleri daha yüksektir.

Örgütsel bağlılık üzerinde yalnızca kişilik değişkenlerinin değil; aynı zamanda örgütsel değişkenlerin de etkisi bulunabilmektedir (Allen ve Meyer, 1990). Bu 
çerçevede adalet algısının örgütsel bağlllık üzerinde etki yapabildiği görülmektedir. Adalet algısındaki artma ya da azalma, örgütsel bağlılığı etkilemekte (Ambrose, 2002; Bakhshi, 2009); örgütsel adalet alg1sının artması, örgüte bağlılığın artmasını beraberinde getirmekte (Tikanmaki, 2001; Loi vd., 2006, Dailey vd., 1992, Konovsky vd., 1987, Sweeney vd., 1993); azalması da, bağlılığın azalmasına neden olmaktadır (Cropanzano vd., 1997; Varoğlu, 1993). Bu bağlamda aşağıdaki hipotezin test edilebileceği değerlendirilmektedir:

Hipotez 5. Örgüt içinde bireylerin algıladı̆̆ı adalet, örgütsel bağllıkları üzerinde etkilidir.

Örgütsel bağlılık, doğal olarak, birçok davranışsal sonuç yaratabilmektedir. Örnekleyecek olursak, örgütsel bağlılık geliştirmiş bireylerin performansı yüksek olmakta, bu bireyler daha az iş devamsızlığı yapmakta ve daha fazla örgütsel vatandaşlık davranış1 göstermektedir (Allen ve Meyer, 1996; Gautam vd., 2005; Meyer vd., 2002). Ayrica, bireylerin mevcut durumlarını korumak ve kişiler ya da kurumlar arasında karşlıklı fayda kazanmak gibi amaçlarla da, örgütsel bir bağlılık geliştirememiş olanlara göre daha çok vatandaşlık davranışları göstermekte oldukları belirtilmektedir (Bogler ve Somech, 2004; Gautam vd., 2005). Bununla birlikte, örgütsel bağllllğın boyutlarından normatif bağlllığa sahip kişilerin, sorumluluk ve ahlâki yükümlülük duygusu ile örgütleri için iyi olanı yapmaya ve uygun iş davranışları göstermeye çalışması, bu kişilerin daha fazla ișe katılım ve örgütsel vatandaşlık davranışları göstermelerini beraberinde getirebilmektedir (İnce ve Gül, 2005; Meyer ve Allen, 1997). Bu gerekçelerle aşağıdaki hipotez oluşturulmuştur:
Hipotez 6. Bireylerin örgütsel bağlllikları, örgütsel vatandaşlık davranışları üzerinde etkilidir.

Buraya kadar çizilmeye çalışllan kuramsal çerçeve, kontrol odağı, adalet algısı, bağll lık ve örgütsel vatandaşlık davranışı arasındaki ilişkileri ifade etmektedir. Yukarıda ifade edilen kuramsal ve görgül bulgulara dayanan sonuçlar, bireylerin iç kontrol odaklı olması ile adalet algısı, bağlllık ve örgütsel vatandaşlık davranışı gösterme düzeylerinin yükselebileceğini; artan adalet algısının örgütsel vatandaşlık davranışları ve bağlllık üzerinde olumlu etkisi olabileceğini; benzer şekilde, artan bağlllığın da ÖVD üzerinde olumlu etki yaratabileceğini göstermektedir. Bu durum, kontrol odağının bireylerin örgütsel vatandaşlık davranışı üzerinde hem doğrudan etkisi olabileceğini hem de ÖVD üzerinde etkili olan, adalet algısı ve bağlılık üzerinden dolaylı olarak da etkili olabileceğini; başka bir deyişle, adalet algısı ve bağlılığın aracılık etkisinin bulunabileceğini ifade etmektedir. Benzer şekilde ÖVD üzerinde doğrudan etkisi olan adalet algısının; doğrudan bağlılık üzerinde, dolaylı olarak da ÖVD üzerinde etkili olabileceği değerlendirilmektedir.

Buraya kadar açıklanmaya çalışılan gerekçelerden hareketle, bu çalışma, kontrol odağı, adalet algısı, bağll1ık ve örgütsel vatandaşlık davranışı arasındaki ilişkileri bütünsel bir yaklaşımla ortaya koyabilecek, yukarıda sıralanan hipotezleri bu bütüncül yapı içindeki karşılıklı ilişkiler çerçevesinde test edebilecek, ayrıca, bu ilişkiler içinde anılan faktörlerin doğrudan ve dolaylı etkilerini bir arada görmeyi sağlayabilecektir. $\mathrm{Bu}$ çerçevede kurgulanan model ve oluşturulan hipotezler Şekil. 1' de gösterilmiştir.

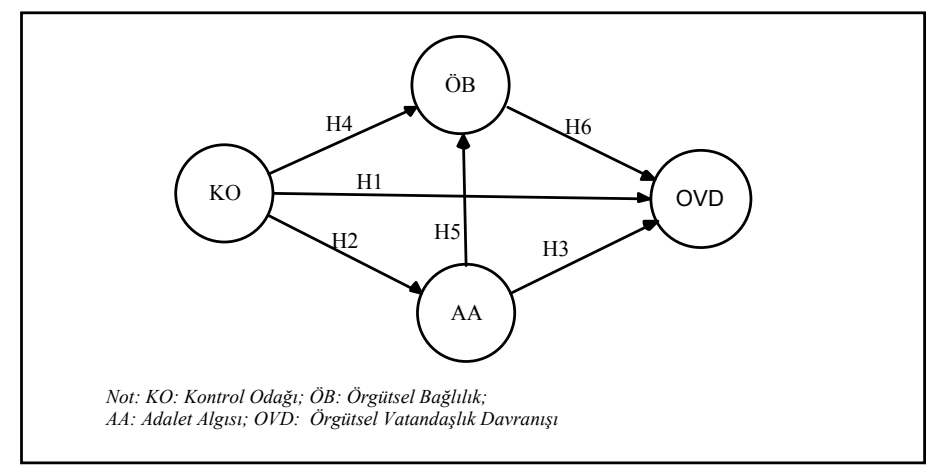

Şekil 1. Araştırma Modeli ve Hipotezler 
ÖVD’nin öncülleri ile olan ikili ilişkileri inceleyen çalışmalar (Lepine vd., 2002; Organ ve Ryan, 1995; Podsakoff vd., 2000) olmakla beraber, bu değişkenleri, bir yapısal eșitlik modeli çerçevesinde bir arada ele alan çalışmalara rast gelinmemiştir. Bu çerçevede, ÖVD ve onu destekleyen üç değişkenin birlikte ele alınması ve modeldeki tüm değişkenler arasındaki karşılıklı ilişkilerin görülebilmesinin, bu çalışmanın önemini artırdığı değerlendirilmektedir.

\section{Yöntem}

\section{Katılımcılar}

Araştırmaya, çeşitli Bakanlıklar ve bunların Ankara’daki bağl1/ilgili kuruluşlarında; şef, kısım amiri ve şube müdürü pozisyonlarında görev yapan 232 alt ve orta kademe yöneticisi katılmıştır. Katılımcı olarak yöneticilerin seçilmesi, bu grubun çalışmanın kuramsal çerçevesine ve bağlamına uygun bir grup olmasidır. Katılımcıların yaşları 25 ile 42 yıl arasında (Ort= $35,08, S=4,14)$; kurumda çalışma süreleri ise 5 ile 23 yll arasında değişmektedir (Ort $=12,05, \mathrm{~S}=4,61)$. Katılımcların \%81,9'u ( $\mathrm{n}=190)$ lisans ve $\% 18,1^{\prime} \mathrm{i}(\mathrm{n}=42)$ de yüksek lisans derecesine sahiptir.

\section{Veri Toplama Araçları}

\section{Kontrol Odağı Ölçeği}

"İç-Dış Kontrol Odağı Ölçeği” Rotter (1966) tarafından geliştirilmiş ve Türkçeye uyarlama çalışmaları Dağ $(1991 ; 2002)$ tarafından yapılmıştır. Ölçek, bireylerin genellenmiş kontrol beklentilerinin içsellik-dışsallık boyutu üzerindeki konumunu; pekiştiricilerin bireyin kendi içindeki ya da dışındaki güçlerin (ör: şans, kader vb.) kontrolünde olduğuna dair sahip olduğu genel beklenti ya da inancı ölçmektedir. 29 maddeden oluşan ölçeğin her bir soru maddesine ilişkin cevapları a ve b olmak üzere iki seçeneklidir. Bireyler ölçeği yanıtlarken her bir soru maddesine ilişkin kendisine uygun gelen cümleyi a ve b şeklinde işaretlemektedirler. Ölçeğin puanlanmasında ise, 29 maddenin 6'sı dolgu maddesi olduğu için puanlama sürecine katılmamakta, geriye kalan sorulardan maddelere verilen cevaplar puanlanmakta ve sonuçta bireyler 0 ile 23 arasında puan alabilmektedir. Yükselen puanlar dış kontrol odağı inancındaki artışı göstermektedir.

Rotter'in İç-Dış Kontrol Odağı Ölçeğinin (RİDKOÖ) ülkemizde yapılan araştırmalarda (Basım ve Şeșen, 2006a; Savaşır ve Şahin, 1997; Tatar, 2006) sıklıkla kullanıldığı görülmektedir. Bu çalışmada ölçeğin iç tutarlılığ 1,95 olarak hesaplanmıştır.

\section{Örgütsel Adalet Algısı Ölçeği}

Örgütsel adalet algısı ölçeği (ÖAAÖ), İşbaşı (2000; 2001) tarafından daha önce kullanılmış olan farklı ölçeklerdeki (Moorman 1991; Niehoff ve Moorman 1993; Folger ve Konovski, 1989) maddeler kullanılarak geliştirilmiştir. Ölçek, bölüşümsel adalet (7 madde), süreç adaleti (7 madde), etkileşim adaleti (13 madde) alt boyutlarından oluşmaktadır. Ölçekte, "Kurumun işleyişine yönelik kurallar, yöneticinin karar alabilmesi için gerekli olan doğru bilgileri sağlar", "Kurumun kaynaklarından ihtiyaçlarımız ölçüsünde eşit biçimde yararlanabiliriz" ya da "Amirimiz, düşüncelerimizi dikkate alır" gibi ifadelerden oluşan 27 madde yer almakta ve katılımcılara beşli Likert tipinde belirtilen bu ifadeleri hangi katılım düzeyinde (1- Hiç Katılmıyorum; 5- Tamamen Katılıyorum) onayladıkları sorulmaktadır. Ölçeğin İşbaşı (2000)'nın çalışmasında boyutlarına ait iç tutarlılık katsayıları, 71 ve, 91 arasında değişmiş, ölçeğin tamamı için ise , 92 olarak tespit edilmiştir.

Ölçek ülkemizde farklı araştırmacılar tarafından kullanılmıştır (Aslantaş ve Pakdemir, 2007; Dilek, 2004; İşbaşı, 2000; 2001; Özmen vd., 2001). Bu çalışmada da ölçeğin iç tutarlılığı ,95 olarak hesaplanmıştır.

\section{Örgütsel Bağlılık Ölçeği}

Katılımcıların örgütsel bağlllık seviyelerini ölçmek için Meyer ve arkadaşlarının (1993) geliştirdiği ve Wasti’nin (2000) bazı eklemeler yaparak Türk kültürüne uyarladığı Örgütsel Bağlılık Ölçeğinin (ÖBÖ), 8 ifadeden oluşan Duygusal Bağll1lk alt ölçeği ile 7 ifadeden oluşan Ahlâki (Normatif) Bağlılık alt ölçekleri kullanılmıştır. Alınan yüksek puanlar yüksek bağlılığı göstermektedir.

Soru maddelerinde "Bu kuruluşun benim için özel bir anlamı var" ya da "Bu kuruluş benim sadakatimi hak ediyor" türünden ifadeler yer almaktadır. Bireylere, kendi kurumlarını göz önünde bulundurarak, bu kurumda çalıştıkları süre içinde karşılaştıkları gerçek durumları ve onlarda oluşan kanaatleri en iyi yansitan ifadeleri işaretlemeleri istenmiştir. Katılımcılara beşli Likert tipinde belirtilen ifadeleri hangi katılım düzeyinde (1- Hiç Katılmıyorum; 5- Tamamen Katılıyorum) onayladıkları sorulmaktadır.

Ölçek ülkemizde farklı araştırmacılar tarafından kullanılmıştır (Basım vd., 2009; Dilek, 2005; Ceylan ve 
Bayram, 2006; Meydan, 2010; Özdevecioğlu, 2003; Poyraz ve Kama, 2008). Bu çalışmada ölçeğin iç tutarlılığ 1,91 olarak hesaplanmıştır.

\section{Örgütsel Vatandaşlık Davranışı Ölçeği}

Örgütsel Vatandaşlık Davranışı Ölçeği (ÖVDÖ). Çalışanların örgütsel vatandaşlık davranışlarını ölçmek için, iki ayrı çalışmadan (Vey ve Campbell, 2004; Williamse ve Shiaw, 1999) yararlanılarak, Basım ve Şeşen (2006b) tarafından geliştirilen ölçek kullanılmıştır. Ölçekte "Aşırı iş yükü ile uğraşan bir kurum çalışanına yardım ederim", "Mesai içerisinde kişisel işlerim için zaman harcamam”, "Önemsiz sorunlar için şikâyet ederek vaktimi boşa harcamam”, "Kurum yapısında gerçekleştirilen değişikliklere destek olurum" gibi yargı cümlelerinden oluşan 19 madde yer almaktadır. Ölçek, örgütsel vatandaşlık davranışını, Organ (1988) tarafından ortaya konulan diğerkâmlık (5 madde), vicdanlllik (3 madde), nezaket ( 3 madde), centilmenlik (4 madde) ve sivil erdem (4 madde) boyutları altında ölçmek üzere tasarlanmıştır. Anket katılanlardan bu yargı cümlelerine hangi oranda ka- tıldıklarını 6’lı Likert tipi ölçek üzerinde, "hiçbir zaman" ile "her zaman" arasında değişen bir sıklık aralığında işaretlemeleri istenmiştir.

Basım ve Şeşen (2006b)'in ölçek geliştirme çalışması kapsamında iki ayrı örneklemde güvenilirlik analizi yapılmış; birinci örneklem için ölçeğin iç tutarlılığının ,89 olduğu görülmüş, ikinci örneklemde ölçeğin iç tutarlılığ 1,94 olarak hesaplanmıştır. Mevcut çalışmada ise ölçeğinin iç tutarlıllı̆̆ 1,87 olarak bulunmuştur.

\section{Ölçeklerin Geçerliliği}

Kullanılan ölçeklerin geçerliliğini test etmek için doğrulayıcı faktör analizi (DFA) yapılmıştır. DFA ile RİDKOÖ’nin tek faktörlü yapısı, ÖAAÖ’nün üç faktörlü yapısı (bölüşümsel adalet, süreç adaleti ve etkileşim adaleti), ÖBÖ’nün iki faktörlü yapısı (duygusal bağll1ık ve normatif bağlılık) ve ÖVDÖ’nün beş faktörlü yapısı (diğerkâmlık, vicdanlılık, nezaket, centilmenlik ve sivil erdem) test edilmiştir. Tablo 1'de sunulan doğrulayıcı faktör analizi bulgularından anlaşılacağı üzere, anılan faktör yapıları doğrulanmıştır.

Tablo 1. Ölçeklerin Doğrulayıcı Faktör Analizi Sonuçları

\begin{tabular}{|c|c|c|c|c|c|c|}
\hline Ölçek & $\Delta \chi^{2}$ & df & $\Delta \chi^{2} / \mathbf{d f}$ & RMSEA & CFI & IFI \\
\hline RIDKOÖ & $139,6^{*}$ & 115 & 1,214 &, 043 & ,911 & ,917 \\
\hline ÖAAÖ & $351,3^{*}$ & 206 & 1,71 & ,081 & ,927 & ,923 \\
\hline ӦвÖ & $69,98^{*}$ & 34 & 2,06 & 102 & ,902 & 918 \\
\hline ÖVDÖ & $211,20^{*}$ & 146 & 1,44 &, 063 & ,937 & ,942 \\
\hline
\end{tabular}

Uyum indeks değerleri ele alındığında, RMSEA haricindeki indeks değerlerinin istenen düzeyde $(\mathrm{Hu}$ ve Bentler, 1999) olduğu, RMSEA değerinin istenen limitin üzerinde olmasının ise de örneklem sayısının küçük olmasından kaynaklandığı (Tabachnick ve Fidel, 2001) değerlendirilmiş ve sonuç olarak ölçeklerin kabul edilebilir geçerlilikte olduğu belirlenmiştir.

\section{İşlem}

Araştırmada kullanılan ölçeklere demografik değişkenler de eklenerek bir araya getirilmiş ve bir veri toplama formu hazırlanmıştır. Veriler, ölçüm araçlarının, yüz yüze iletişimle ve nezaret altında uygulan- ması ile elde edilmiştir. Bireylere araştırmanın amacı konusunda kısa bilgi verilmiş, uygulama süresi 15-20 dakika arasında değişmiştir. Veri analizleri SPSS ve AMOS programlarıyla yapılmıştır.

\section{Bulgular}

Uygulama sonucunda değişkenlere ve boyutlara ait ortalamalar hesaplanmış ve Tablo 2'de gösterilmiştir. Bireylerin kontrol odağı puanları incelendiğinde, iç kontrol odağı eğiliminin daha hakim olduğu (Ort=7,66, S=4,40), örgütsel adalet algıları incelen- 
diğinde, çalıştıkları kurum ile ilgili adalet algılarının pek yüksek olmadığı $(\mathrm{Ort}=2,56, \mathrm{~S}=, 73)$, örgütsel bağlılık düzeylerinin ortalamanın biraz altında olduğu
$(\mathrm{Ort}=2,80, \mathrm{~S}=, 67)$ ve örgütsel vatandaşlik düzeylerinin ortalamanın üzerinde olduğu $(\mathrm{Ort}=4,75, \mathrm{~S}=, 55)$ görülmektedir.

Tablo 2. Ortalamalar, Standart Sapmalar ve Korelâsyon Değerleri

\begin{tabular}{lcccccc}
\hline Değişken & Ort. & S. & $\mathbf{1}$ & $\mathbf{2}$ & $\mathbf{3}$ & $\mathbf{4}$ \\
\hline 1. Kontrol Odağ & 7,66 & 4,40 & $(, 781)$ & & & \\
2. Adalet Algısı & 2,56 &, 731 &,$- 141^{*}$ & $(, 951)$ & & \\
3. Bağl1lık & 2,80 &, 674 &,$- 146^{*}$ &, $622^{* *}$ & $(, 807)$ & \\
4. Örgütsel Vat. Dvr. & 4,75 &, 551 &,$- 283^{* *}$ &, $268^{* *}$ &, $238^{* *}$ & $(, 856)$ \\
\hline${ }^{*}$ p $<, 05,^{* *} \mathrm{p}<, 01$ & & &
\end{tabular}

Kontrol odağı, adalet algısı, bağlılık ve ÖVD arasındaki korelâsyon incelendiğinde tüm değişkenler arasında istatistiksel olarak anlamlı ilişkiler olduğu görülmektedir. Buna göre kontrol odağ 1 ile adalet algısı arasında zayıf anlamlı ilişki $(\mathrm{r}=-, 141, \mathrm{p}<, 05)$, kontrol odağı ile bağlılık arasında zayıf anlamlı ilişki $(\mathrm{r}=-, 146, \mathrm{p}<, 05)$, kontrol odağ 1 ile ÖVD arasında zayıf anlamlı ilişki $(r=-, 283, p<, 01)$, adalet algısı ile bağlllık arasında orta düzeyin üstünde anlamlı ilişki $(\mathrm{r}=, 622, \mathrm{p}<, 01)$, adalet algısı ile ÖVD arasında zayıf anlamlı ilişki $(r=, 268, p<, 01)$ ve bağlllık ile ÖVD arasında zayıf anlamlı ilişki $(\mathrm{r}=, 238, \mathrm{p}<, 01)$ tespit edilmiştir.
Kontrol odağı, adalet algısı, bağl1lık ve ÖVD arasındaki ilişkiler bir bütün olarak modellenmiş ve modele yönelik yol analizi sonuçları Şekil-2'de gösterilmiştir. Buna göre, kontrol odağı ile adalet algısı arasında zayıf anlamlı ilişki $(\beta=-, 16, p<, 05)$, kontrol odağı ile ÖVD arasında zayıf anlamlı ilişki $(\beta=-, 28, p<, 05)$, adalet algısı ile bağlılık arasında yüksek düzeyde anlamlı ilişki $(\beta=, 72, p<, 01)$, adalet algısı ile ÖVD arasında orta düzeyde anlamlı ilişki $(\beta=, 30, \mathrm{p}<, 05)$ ve bağlılık ile ÖVD arasında zayıf anlamlı ilişki $(\beta=, 08$, $\mathrm{p}<, 01)$ olduğu görülmektedir.

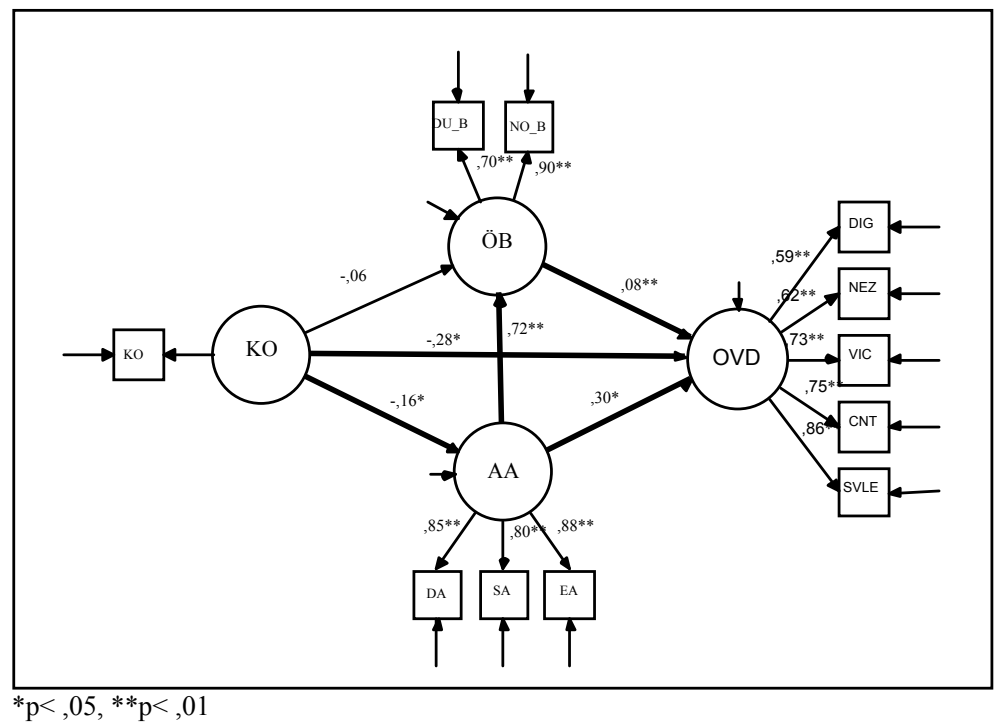

Şekil 2. Yol Analizi Sonuçları 
Kontrol odağının, adalet algısı, bağllilı ve ÖVD, adalet algisının bağlılık ve ÖVD ve bağlllığın ÖVD üzerindeki etkisini ölçümlemek üzere kurulan araştırma modeline yönelik olarak yapılan yol analizinin uyum değerleri de Tablo-3’te verilmiştir. Bu sonuçlar mode-

lin yeterli uyum sağladığını göstermektedir.

Tablo 3. Model Uyum Değerleri

\begin{tabular}{ccccccccc}
\hline$\chi^{2}$ & $\mathbf{p}$ & $\mathbf{d f}$ & $\chi^{2} / \mathbf{d f}$ & RMSEA & GFI & AGFI & IFI & CFI \\
\hline 18,287 &, 248 & 15 & 1,219 &, 038 &, 973 &, 934 &, 993 &, 993 \\
\hline
\end{tabular}

Şekil 1' de gösterilen yol analiz sonuçları, değişkenler arasındaki doğrudan etkileri göstermektedir. Modele yönelik ayrıntılı analiz yapıldığında, doğrudan etkilerin haricinde dolaylı etkileri de ortaya koymak mümkün olabilmektedir. Bir değişkenin diğer değişken üzerindeki dolaylı etkisi bir aracı değişken üzerinden olmakta ve sonuçta bağımlı değişkenin bağımsız değişken tarafından yordanma şekli hakkında daha ayrıntılı bilgiye sahip olunabilmektedir. Bu çalışmada ortaya konmaya çalışllan değişkenlere ait doğrudan, dolaylı ve toplam etkiler aşağıdaki tabloda (Tablo 4) verilmiştir.

Tablo 4. Toplam Doğrudan ve Dolaylı Etkiler

\begin{tabular}{|c|c|c|c|c|c|c|c|c|c|}
\hline & \multicolumn{3}{|c|}{$\begin{array}{l}\text { KONTROL ODAĞI } \\
(\mathbf{K O})\end{array}$} & \multicolumn{3}{|c|}{$\begin{array}{l}\text { ADALET ALGISI } \\
(\mathbf{A A}) \\
\end{array}$} & \multicolumn{3}{|c|}{$\begin{array}{c}\begin{array}{l}\text { ÖRGÜTSEL BAĞLILIK } \\
\text { (ÖB) }\end{array} \\
\end{array}$} \\
\hline & Toplam & $\begin{array}{c}\text { Etkiler } \\
\text { Doğrudan }\end{array}$ & Dolayll & Toplam & $\begin{array}{c}\text { Etkiler } \\
\text { Doğrudan }\end{array}$ & Dolayll & Toplam & $\begin{array}{c}\text { Etkiler } \\
\text { Doğrudan }\end{array}$ & Dolayl \\
\hline $\mathbf{A A}$ &,$- 16^{*}$ &,$- 16^{*}$ & - & - & - & - & - & 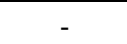 & - \\
\hline ÖB &,- 18 &,- 06 &,- 12 &, $72^{* *}$ &, $72^{* *}$ & - & - & - & - \\
\hline ÖVD &,$- 35^{* *}$ &,$- 28^{* *}$ &,$- 06^{* * *}$ &, $36^{* *}$ &, $30^{*}$ &, $06^{*}$ &, $08^{* *}$ &, $08^{* *}$ & - \\
\hline
\end{tabular}

$* \mathrm{p}<, 05, * * \mathrm{p}<, 01, * * * \mathrm{p}<, 001$

Doğrudan, dolaylı ve toplam etkiler incelendiğinde, kontrol odağının adalet algısı üzerinde doğrudan ve örgütsel vatandaşlık davranışı üzerinde hem doğrudan hem de dolaylı etkisi olduğu, adalet algisının örgütsel bağlllık üzerinde doğrudan ve örgütsel vatandaşlık davranışı üzerinde hem doğrudan hem de dolaylı etkisi olduğu, ayrıca örgütsel bağlılığın örgütsel vatandaşlık davranışı üzerinde doğrudan etkisi olduğu görülmektedir.

Araştırma hipotezleri değerlendirildiğinde iç kontrol odaklı bireylerin, örgüt içinde daha fazla örgütsel vatandaşlık davranışları sergilediğine yönelik hipotez (Hipotez 1) kabul, iç kontrol odaklı bireylerin, örgüt içinde algıladıkları adaletin yüksek olduğuna yönelik hipotez (Hipotez 2) kabul, iç kontrol odaklı bireylerin, örgüte bağlllık seviyelerinin yüksek olduğuna yönelik hipotez (Hipotez 3) ret, örgüt içinde bireylerin algıladığı adaletin, örgütsel vatandaşlık davranışları üzerinde etkili olduğuna yönelik hipotez (Hipotez 4) kabul, örgüt içinde bireylerin algıladığı adaletin, örgütsel bağllılıkları üzerinde etkili olduğuna yönelik hipotez (Hipotez 5) kabul, örgüt içinde bireylerin örgütsel bağlılıklarının, örgütsel vatandaşlık davranışları üzerinde etkili olduğuna yönelik hipotez (Hipotez 6) kabul edilmiştir.

\section{Tartışma}

$\mathrm{Bu}$ çalışmanın amacı örgütsel kontrol odağı, adalet algısı ve bağlılık ile ÖVD arasındaki ilişkiyi inceleyerek, aralarındaki etkileşimi ve kontrol odağı, adalet algısı ve bağlllı̆̆ın ÖVD üzerindeki öncüllük rolünü ortaya koymaktır. Daha önce anılan değişkenler ile ÖVD arasındaki doğrusal ilişkinin ortaya konması- 
na yönelik yapılmış olan çalışmalar bulunmaktadır. Ancak bu çalışma, geçmişteki çalışmalardan farklı olarak, anılan değişkenleri birlikte ele alarak incelemekte ve bütüncül bir bakış açısıyla, odaklanılan ilişkileri ortaya koymak suretiyle hem ilgili yazına katkı sağlamayı hem de yönetsel/örgütsel uygulamalarda yöneticilere kolaylıklar sunacak bulgular elde etmeyi hedeflemektedir.

Elde edilen bulgular kontrol odağının, ÖVD (Blakely vd., 2005; Basım ve Şeşen, 2006a; Hoffi-Hofstetter ve Mannheim, 1999; Spector ve Fox, 2003), örgütsel adalet algısı (Youn, 2007) ve bağlılık (Coleman vd., 1999; Munir ve Sajid, 2010; Wang ve Chen, 2007) üzerindeki etkisini ortaya daha önce yapılmış çalışmaları desteklemektedir. Bunun yanı sıra, örgütsel adalet algısı ile ÖVD arasındaki etkileşime odaklanan daha önce yapılmış çalışmalar desteklenmekte (Chegini, 2009; Ehrhart, 2004; İșbaşı, 2001; Rifai, 2005; Teper ve Taylor, 2003; Zellars vd., 2003), örgütsel bağlllık ve ÖVD arasındaki ilişki de (Allen ve Meyer, 1996; Gautam vd., 2005; Meyer vd., 2002) desteklenmektedir. Bunların yanında tüm değişkenler bir arada ele alındığında, değişkenler arasında dolaylı etkilerin olması, kontrol odağ 1 ÖVD arasındaki ilişkide adalet algısı ve örgütsel bağlllığın; adalet algısı ÖVD arasındaki ilişkide ise örgütsel bağl1lığın aracılık etkisi yaptığı ortaya konmaktadir.

Çalışmanın bulguları incelendiğinde, araştırma hipotezlerine yönelik olarak aşağıdaki yanıtların bulunduğu görülmektedir. İç kontrol odaklı bireyler, örgüt içinde daha fazla örgütsel vatandaşlık davranışları sergilemekte, bu bireylerin örgüt içinde algıladıkları adalet ve örgüte bağllılık seviyeleri yüksek olmaktadır. Ayrıca bireylerin örgüt içinde algıladığı adalet, örgütsel vatandaşlık davranışları örgütsel bağlılıkları üzerinde etkili olmaktadır.

Kontrol odağı eğilimi adalet algısı üzerinde etkiye sahip olabilmekte, iç kontrol odaklı bireylerin adalet algılamaları yüksek olmaktadır. Bu durum, iç kontrol odaklı bireylerin, kazanımlarının dağıtımı, süreçler ve liderleriyle etkileşimlerinin adaletli olmasının kendilerinden kaynakladığı inancında olduğunu göstermektedir. Bunun aksine, dış kontrol odaklı bireyler ise olayları kendileri dışında faktörlere bağlayarak örgüt içinde kazanımların dağıtımını, örgüt içi süreçleri sü- reç ve lider ast arasındaki etkileşimleri adaletli algılamamaktadırlar. Çünkü onlara göre adalet bir şekilde dağıtılmaktadır; bu durum şans ve kadere göre rasgele de olabilmektedir. Örgütsel adalet algısı örgüt içinde çalışanların performansını etkilemekte, lider/yöneticilerinin ve örgüt içi süreçlerin adil olduğunu algılayan çalışanlar daha fazla performans sergileyebilmektedir (Feng-jing ve Chun-sheng, 2008). Bu çerçevede, iç kontrol odaklı bireylerin performanslarının yüksek olmasinda (Jeloudar ve Lotfi-Goodarzi, 2012) adalet algılarının da etkili olduğu değerlendirilmektedir.

Benzer şekilde iç kontrol odaklı bireylerin etkili oldukları ve çevreyi etkileyebildiklerine dair olan inançları, sorumluluk duygularının fazla olması, toplumsal olaylarda daha aktif olmaları, daha bağımsız, daha başarılı, politik açıdan aktif ve kişisel güce sahip olmaları ve motivasyonlarının görece fazla olması, onların hem örgütlerine karşı hem de örgüt içinde iş arkadaşlarına karşı daha iyi tutum sergilemelerine neden olabilmekte (Spector ve Fox, 2003), bunun sonucunda bireyler örgütsel vatandaşlık davranışları sergileyebilmektedir.

Kontrol odağı ile ilişkili bu bulguların yanı sıra, adalet algısının da ÖVD üzerinde doğrudan etkili olduğu görülmektedir. Çalışanlar yöneticilerinin süreçler üzerinde etkili ve adaletli olduğunu değerlendirdiği ve kendileriyle etkileşimlerinde hassas davrandıkları durumlarda ÖVD sergileyebilmektedir (Ball vd.,1994; Skarlicki ve Folger, 1997). Bu çerçevede bu bulgu, bireylerin adalet algılamalarını örgütsel süreçler ile ilişkilendirmekte olmaları ve çalışma arkadaşlarının da örgütün bir parçası olarak görmelerinden kaynaklanabileceği ile açılanabilir.

Örgütsel adalet alg1sı, hem süreçleri içine alan örgüt yapısı ile ilgili adalet algılamalarını, hem de bireylerin liderleri ile aralarındaki etkileşimi içeren adalet algılamalarını kapsamaktadır (Colquitt, 2001). Örgüt içine adalet algılamasının yüksek olması bireylerin bağlllık duyguları üzerinde doğru yönde bir etkiye sahip olmakta, bunun sonucunda ortaya çıkan bağl1lık hissi bireylerin ÖVD sergilemelerinin gücünü artırmaktadır (Bakhshi, 2009; Gautam vd., 2005). Bu çerçevede bireylerin adalet algılaması ile ÖVD sergilemeleri arasındaki ilişkide örgütsel bağlılığın aracılık ettiği söylenebilir. 
Ulaşılan bulgular bireylerin ÖVD göstermesinde bireylerin kontrol odağı eğiliminin, adalet algısının ve örgütsel bağlllı̆̆ının önemli birer örgütsel değişken olduğunu; aynı zamanda bireylerin kontrol odağı inancının örgütsel diğer değişkenler üzerinde etkili olduğunu göstermektedir. Zira kontrol odağ 1 hem adalet algisı üzerinde hem de ÖVD üzerinde etkili olabilmektedir.

Araştırmanın örnekleminin alt ve orta kademe yöneticiler olduğu göz önüne alındığında, ulaşılan bulguların yönetsel/örgütsel ortam ve uygulamalar için kullanılabileceği ve bu çerçevede yarar sağlayabilecek bazı sonuçları ortaya koyduğu değerlendirilmektedir. Örgütsel başarı, verimlilik ve etkililiğin artmasında önemli bir faktör olan ÖVD’nin iç kontrol odağına sahip bireyler tarafından daha fazla sergilendiği, bu nedenle bu durumun personel seçiminde dikkate alınabileceği görülmektedir. Ayrıca örgüt içinde adalet algılamalarının yükseltilmesine yönelik alınacak tedbirler hem bireylerin örgüte olan bağlllıklarının artmasına hem de örgütsel vatandaşlık göstermesine neden olabilecektir. Bu durum, bireylerin hem iş arkadaşlarına hem de iş yerlerine karşı gösterdikleri örgütsel vatandaşlık davranışlarını olumlu olarak etkileyebilecek, sonuçta da örgütsel performansı artırabilecektir.

Bu bulguların yanında çalışmamız bazı sınırlılıklar da içermektedir. Her şeyden önce araştırma katılımcılarının sayısı yapısal model testi açısından yeterli olsa da (Hair vd., 2005) bir sinırlılık olarak göze alınmal1dır. Ayrıca katılımcılar kamu sektöründe belirli pozisyonlarda görev yapan, belirli sayıda yöneticiden oluşmaktadır. Bu durum da bir sınırlılığa işaret etmektedir. Dolayısıyla, nicel ve nitel olarak farklı örneklem gruplarıyla yürütülecek çalışmalar daha genellenebilir sonuçlara ulaşma imkânı sağlayabilecektir. Bunların yanı sıra, veriler kişilerin yalnızca kendi değerlendirmelerini yansıttığından, ortak yöntem varyansı ve sosyal beğenirlik etkisi sınırlılıkları ile araştırmanın kesitsel veri kullanılarak gerçekleştirilmiş olması, sonuçların değerlendirilmesinde dikkate alınmalıdır.

\section{Kaynakça}

Allen, N.J. ve Meyer, J.P. (1990). The measurement and antecedents of affective, continuance and normative commitment to the organization. Journal of Occupational Psychology, 63, 1-18.

Ambrose, M. (2002). Contemporary justice research: A new look at familiar questions. Organizational Behavior and Human Decision Processes, 89, 803812.

Anderson A., Hattie, J. ve Hamilton, R.J. (2005). Locus of control, self-efficacy, and motivation in different schools: Is moderation the key to success? Educational Psychology, 25(5), 517-535.

Anderson, C.R. (1977). Locus of control, coping behaviors and performance in a stress setting: A longitudinal study. Journal of Applied Psychology, 62, 446-451.

Andersson-Stråberg, T., Sverke, M. ve Hellgren, J. (2007). Perceptions of justice in connection with individualized pay setting. Economic and Industrial Democracy, 28(3), 431-464.

Arslantaş, C. ve Pekdemir, I. (2007). Dönüşümcü liderlik, örgütsel vatandaşlık davranışı ve örgütsel adalet arasındaki ilişkileri belirlemeye yönelik görgül bir araştırma. İstanbul Üniversitesi Sosyal Bilimler Dergisi, 1, 261-285.

Ball, G. A., Trevino, L. K., ve Sims Jr., H. P. (1994). Just and unjust punishment: Influences on subordinate performance and citizenship. Academy of Management Journal, 37, 299-322.

Barksdale, K. ve Werner, J.M. (2001). Managerial ratings of in-role behaviors, organizational citizenship behaviors and overall performance: Testing different models of their relationship. Journal of Business Research, 51, 145-155.

Basım, H. N. ve Şeşen, H. (2006a). Kontrol odağının çalışanların nezaket ve yardım etme davranışlarına etkisi: Kamu sektöründe bir araştırma. Selçuk Üniversitesi Sosyal Bilimler Enstitüsü Dergisi, 23, 159-168. 
Basım, H. N. ve Şeşen, H. (2006b). Örgütsel vatandaşlık davranışı ölçeği uyarlama ve karşılaştırma çalışması. Ankara Üniversitesi SBF Dergisi, 61(4), 83-102.

Basım, H. N., Meydan, C.H. ve Şeşen, H. (2009). Bireyin Örgütsel Adalet Algısının İç Girişimcilik Davranışı İle İlişkisi: Kamuda Bir Araştırma. İktisat Issletme ve Finans, 24, 274, 79-99.

Bateman, T.S. ve Organ, D.W. (1983). Job satisfaction and the good soldier: The relationship between affect and employee citizenship. Academy of Management Journal, 26, 587-595.

Beugre, C.D. ve Baron, R.A. (2001). Perceptions of systemic justice: The effects of distributive, procedural, and interactional justice. Journal of Applied Social Psychology, 31(2), 324-339.

Bies, R. ve Moag, J. (1986). Interactional justice: Communication criteria of fairness, Sheppard, B.H. ve Bazerman, M.H. (Ed.) Research on Negotiation in Organizations, 1, Greenwich, CT: JAI Press, 43-55.

Blakely, G.L., Srivastava A. and Robert Moorman, H. (2005). The effects of nationality work role centrality, and work locus of control on role definitions of OCB, Journal of Leadership \& Organizational Studies, 12(1), 103-117.

Bogler, R. ve Somech, A. (2004). Influence of teacher empowerment on teachers' organizational commitment, professional commitment and organizational citizenship behavior in schools. Teaching and Teacher Education, 20, 277-289.

Bolino, M.C. (1999). Citizenship and impression management: Good soldiers or good actors? Academy of Management Review, 24(1), 82-98.

Bommer, W. ve Lily, B. (1999). supervisors as stewards of organizational citizenship, an examination of the agreement between within and across group effects of employee OCB's on the overall performance. National Meeting of the Academy of Management, Chicago, IL.

Brennan, A. ve Skarlicki, D.P. (2004). Personality and perceived justice as predictors of survivors' reactions following downsizing. Journal of Applied Social Psychology, 34, 6, 1306-1328.
Brief, A.P.ve Motowidlo, S.J. (1986). Prosocial organizational behaviors. Academy of Management Review, 11(4), 710-725.

Burns, B.M. ve Collins, R.W. (2000). Organizational citizenship behavior in the US context. http//hsb. baylor.edu/ramsower/acis/papers/burns.htm, Erişim T: 21.01.2010.

Bush, J. (1988). Job satisfaction, powerlessness, and locus of control. Western Journal of Nursing Research, 10(6), 718-731.

Ceylan, C. ve Bayram, N. (2006). Mesleki bağlılığın örgütsel bağlllık ve örgütten ayrılma niyeti üzerine etkilerinin düzenleyici değişkenli çoklu regresyon ile analizi, Atatürk Üniversitesi İktisadi ve İdari Bilimler Dergisi, 20(1), 105-120.

Chatman J.A. (1989). Improving interactional organizational research: A Model of person-organization fit. The Academy of Management Review, 14(3), 333-349.

Chegini, M.G. (2009). The relationship between organizational justice and organizational citizenship behavior. American Journal of Economics and Business Administration, 1(2), 171-174.

Cohen-Charash, Y. ve Spector, P.E. (2001). The role of justice in organizations: A meta-analysis. Organizational Behavior and Human Decision Processes, $86,278-321$.

Coleman, D.F., Irving, G.P. ve Cooper, C.L. (1999). Another look at the locus of control-organizational commitment relationship: It depends on the form of commitment, Journal of Organizational Behavior, 20, 995-1001.

Colquitt, J.A. (2001). On the dimensionality of organizational justice: A construct validation of a measure. Journal of Applied Psychology, 86, 386-400.

Colquitt, J.A., Conlon, D.E., Wesson, M.J., Porter, C.O. ve Ng, K.Y. (2001). Justice at the millennium: A meta-analytic review of 25 years of organizational justice research. Journal of Applied Psychology, 86, 425-445.

Dağ, İ. (1991). Rotter'in iç-diş kontrol odaği ölçeğinnin (RIDKOÖ) üniversite öğrencileri için güvenirliği ve geçerliği. Türk Psikoloji Dergisi, 7(26), 10-16. 
Dağ, İ. (2002). Kontrol odağı ölçeği (KOÖ): Ölçek geliştirme, güvenirlik ve geçerlik çalışması, Türk Psikoloji Dergisi, 17 (49), 77-90.

DeCotiis, T.A. ve Summers, T.P. (1987). A path analysis of a model of the antecedents and consequences of organizational commitment. Human Relations, 40 (7), 445-470.

Deluga, R.J. (1995). The relation between trust in the supervisor and subordinate organizational citizenship behavior. Military Psychology, 7(1), 1-16.

Diesterhaft, K. ve Gerken, K. (1983). Self-Concept and locus of control as related to achievement of junior high students. Journal of Psychoeducational Assessment, 12(1), 367-375.

Dilek, H. (2005). Liderlik tarzlarının ve adalet algısını;; örgütsel bağlllık, iş tatmini ve örgütsel vatandaşllk davranışı üzerine etkilerine yönelik bir araştırma, Yayımlanmamış Doktora Tezi, Gebze Yüksek Teknoloji Enstitüsü.

DiPaola, M.F. ve Tschannen-Moran, M. (2001). Organizational citizenship behavior in schools and its relationship to school climate. Journal of School Leadership, 11, 424-447.

Ehrhart, M.G. (2004). Leadership and procedural justice climate as antecedents of unit-level organizational citizenship behavior. Personnel Psychology, 57, 61-94.

Elanain, H.M.A. (2007). The five-factor model of personality and organizational citizenship behavior in united arab emirates, SAM Advanced Management Journal, 72(3), 47-57.

Elise, R.H., Bryan, H. ve Kathleen, C. (1998). Adolescent health: The relationships between health locus of control, beliefs and behaviours. Guidance, \& Counseling, 13(3), 23-30.

Fazey, D.M.A. ve Fazey, J.A. (2001). The potential for autonomy in learning: Perceptions of competence, motivation and locus of control in first-year undergraduate students. Studies in Higher Education, 26(3), 345-361.

Feng-jing, Han ve Chun-sheng Shi, (2008). Relationship of perceived organizational justice and employee performance, Management Science and Engineering, 2008. ICMSE 2008. $15^{\text {th }}$ Annual Conference Proceedings., International Conference on 10-12 Sept. 2008, 1067-1071.
Folger, R. ve Konovsky, M.A. (1989). Effects of procedural and distributive justice on reactions to pay raise decisions. Academy of Management Journal, $32,115-130$.

Gautam T., Van Dick R., Wagner U., Upadhyay N. ve Davis A.J. (2005). Organizational citizenship behavior and organizational commitment in Nepal. Asian Journal of Social Psychology, 8, 3, 305-314.

George, J.M. ve Jones, G.R. (1997). Organizational spontaneity in context. Human Performance, 10, 153-170.

Greenberg, J. (1990). Organizational justice: Yesterday, today, and tomorrow. Journal of Management, 16, 399-432.

Greenberg, J. (1993). Justice and organizational citizenship: A commentary on the state of the science. Employee Rights and Responsibilities Journal, 6, 1-8.

Hair, J.F., Black, B., Babin B., Anderson, R.E. ve Tahtam R.L. (2005). Multivariate Data Analysis (6. Ed.). Upper Saddle River, NJ: Prentice Hall.

Hartman, S.J., Yrle, A.C. ve Galle, W.P. (1999). Procedural and distributive justice: Examining equity in a university setting. Journal of Business Ethics, 20 (4), 337-351.

Hoffi-Hofstetter, H. ve Mannheim, B. (1999). Managers' coping resources, perceived organizational patterns, and responses during organizational recovery from decline. Journal of Organizational Behavior, 20, 665-685.

Hollenbeck, J.R., Williams, C.R. ve Klein, H.J. (1989). An empirical examination of the antecedents of commitment to difficult goals. Journal of Applied Psychology, 74, 18-23.

İnce, M. ve Gül, H. (2005). Yönetimde Yeni Bir Paradigma: Örgütsel Bă̆lllık, Konya, Çizgi Kitabevi.

İşbaşı, J.Ö. (2000). Çalışanlarm Yöneticilerine Duydukları Güvenin ve Örgütsel Adalete İlişkin Algılamalarının Vatandaşlik Davranışının Oluşumundaki Rolü: Bir Turizm Örgütünde Uygulama, Yayımlanmamış Yüksek Lisans Tezi, Akdeniz Üniversitesi, SBE. 
İşbaşı, J.Ö. (2001). Çalışanların yöneticilerine duydukları güvenin ve örgütsel adalete ilişkin algılamalarının vatandaşlık davranışının oluşumundaki rolü, Yönetim Araştırmaları Dergisi, 1(1), 51-73.

Jeloudar, S.Y. ve Lotfi-Goodarzi, F. (2012). Predicting Teachers' Locus of Control and Job performance among MA and BA Teachers Senior Secondary Schools, International Journal of Humanities and Social Science, 2( 12), 248-252.

Kidder, D. L. (2002). The Influence of gender on the performance of organizational citizenship behaviors, Journal of Management, 28(5), 629-648.

Kidwell, R., Mossholder, K. ve Benneth, N. (1997). Cohesiveness and organizational citizenship behavior, Journal of Management, 23(6), 775-793.

Konovsky, M.A. ve Pugh, S.D. (1994). Citizenship behavior and social exchange. Academy of Management Journal, 37, 656-669.

Lee, J. (2001). Leader-member exchange, perceived organizational justice, and cooperative communication. Management Communication Quarterly, 14(4), 574-589.

Lepine, J.A., Erez, A. ve Johnson, D.E. (2002). The nature and dimensionality of organizational citizenship behavior: A critical review and meta-analysis. Journal of Applied Psychology, 87, 52-65.

Li, N., Liang, J. ve Crant, J. M. (2010). The role of proactive personality in job satisfaction organizational citizenship behavior: A relational perspective. Journal of Applied Psychology, 95(2), 395-404.

Libert, Y., Janne, P., Razavi, D., Merckaert, I., Scalliet, P., Delvaux N., Etienne, A-M., Conradt, S., Klastersky, J., Boniver J. ve Reynaert, Ch. (2003). Impact of medical specialists' locus of control on communication skills in oncological interviews. British Journal of Cancer, 88(4), 502-509.

Loosemore, M. ve Lam, A.S.Y. (2004). The locus of control: A determinant of opportunistic behaviour in construction health and safety. Construction Management and Economics, 22: 385-394.

Malki, R. (1998). Davranışlarda Iç-Dış Kontrol Odağı ile Ruh Sağlığı Arasındaki ilişkinin incelenmesi. Yayınlanmamış Yüksek Lisans Tezi. İzmir: Ege Üniversitesi Sosyal Bilimler Enstitüsü.
Martin, R., Thomas, G., Charles, K., Epitropaki, O. ve McNamara, R. (2005). The role of leader member exchanges in mediating the relationship between locus of control and work reactions. Journal of Occupational and Organizational Psychology, 78, 141-147.

Mcneely, B.L ve Meglino, B.M. (1994). The role of dispositional and situational antecedents in prosocial organizational behavior: An examination of the intended beneficiaries of prosocial behavior. Journal of Applied Psychology, 79(6), 836-844.

Meyer J.P. ve Allen N.J. (1991). A three-component conceptualization of organizational commitment, Human Resource Management Review, 1(1), 61-89.

Meyer, J.P. ve Allen N.J. (1997). Commitment in the Workplace: Theory, Research and Application, Thousand Oaks, SAGE Publications.

Meyer, J.P., Allen, N.J. ve Smith, C.A. (1993). Commitment to organizations and occupations: some methodological considerations. Journal of Applied Psychology, 78, 538-551.

Meyer, J.P., Stanley, D.J., Herscovitch, L. ve Topolnytsky, L. (2002). Affective, continuence, and normative commitment to the organization: a meta-analysis of antecedents, corralates, and consequences. Journal of Vocational Behavior, 61, 20-52.

Moon, H., Van Dyne, L. ve Wrobel, K. (2005). The circumplex model and the future of organizational citizenship behavior research. Turnipseed, D.L. (Ed.), Handbook of Organizational Citizenship Behavior: A Review of 'Good Soldier' Activity in Organizations, Nova Science Publishers, New York, NY.

Moorman, R. H. (1991). Relationship between organizational justice and organizational citizenship behaviors: do fairness perceptions influence employee citizenship?, Journal of Applied Psychology, $76,845-855$.

Moorman, R.H., Niehoff, B.P. ve Organ, D.W. (1993). Treating employees fairly and organizational citizenship behavior: Sorting the effects of job satisfaction, organizational commitment, and procedural justice. Employee Responsibilities and Rights Journal, 6, 209-225.

Munir S. ve Sajid M. (2010). Examining locus of control (LOC) as a determinant of organizational commitment among university professors in pakistan. Journal of Business Studies Quarterly, 1(3), 78-93. 
Nasurdin N. ve Khuan J. (2007). Organizational justice as an antecedent of job performance. Gadjah Mada International Journal of Business, September-December, 9(3), 325-343.

Netemeyer, R., Mc Kee, D.O. ve Mc Murran, R. (1997). An investigation into the antecedents of organizational citizenship behavior in a personnel selling context. Journal of Marketing, 61(3), 85-98.

Ng, T.W.H., Sorensen, K.L. ve Eby, L.T. (2006). Locus of control at work: A meta-analysis. Journal of Organizational Behavior, 27, 1057-1087.

Niehoff. B.P. ve Moorman. R.H. (1993). Justice as a mediator of the relationship between methods of monitoring and organizational citizenship behavior. Academy of Management Journal. 36: 527-556.

Nowakovski, J.M. ve Conlon, D.E. (2005). Organizational justice: looking back, looking forward. International Journal of Conflict Management, 16(1), 4-29.

O'Brien K.E. (2004). Self-Determination Theory and Locus of Control as Antecedents of Voluntary Workplace Behaviors. Yayımlanmamış Yüksek Lisans Tezi, University of South Florida, College of Arts and Sciences, Department of Psychology, Tampa, FL.

O'Reilly, C. ve Chatman J. (1986). Organizational commitment and psychological attachment: The effects of compliance, identification and internalization on prosocial behaviour. Journal of Applied Psycho$\log y, 71(3), 492-499$.

Oliver, J.E., Jose, P.E. ve Brough, P. (2006). Confirmatory factor analysis of the work locus of control scale, Educational and Psychological Measurement, $66,835-851$.

Organ, D.W. (1988). Organizational Citizenship Behavior: The Good Soldier Syndrome, Lexington, England: Lexington Books.

Organ, D.W. (1990). The motivational basis of organizational citizenship behavior. Research in Organizational Behavior, 12, 43-72.

Organ, D.W. (1998). Personality and organizational citizenship behavior. Group Organization Management, 23(2), 189-216.
Organ, D.W. ve Moorman, R.H. (1993). Fairness and organizational citizenship behavior: What are the connections? Social Justice Research, 6, 5-18.

Organ, D.W. ve Konovsky, M. (1989). Cognitive versus affective determinants of organizational citizenship behavior. Journal of Applied Psychology, 74(1), 157-164.

Organ, D.W. ve Ryan K.A. (1995). A Meta-Analytic Review of Attitudinal and Dispositional Predictors of Organizational Citizenship Behavior. Personnel Psychology, 48, 775-802.

Ortiz, L. (2000). Explaining job satisfaction's effects on entrepreneurship and turnover intent. Southwest Academy of International Business. San Antonio, Texas.

Ozolins, A.R. ve Stenstrom, U. (2003). Validation of health locus of control patterns in swedish adolescent. Adolescence, 38(152), 650-658.

Özdevecioğlu, M. (2003). Algılanan örgütsel destek ile örgütsel bağllılı arasındaki ilişkilerin belirlenmesine yönelik bir araştırma, Dokuz Eylül Üniversitesi İ.İ.B.F. Dergisi, 18(2), 113 -130.

Özmen, Ö.N.T., Arbak, Y. ve Özer, P.S. (2007). Adalete verilen değerin adalet algıları üzerindeki etkisinin sorgulanmasına ilişkin bir araştırma, Ege Akademik Bakış, 7(1), 17-33.

Podsakoff, P.M., Mackenzie, S.B., Moorman, R.H. ve Fetter, R. (1990). Transformational leader behaviors and their effects on followers: Trust in leader, satisfaction and organizational citizenship behaviors. Leadership Quarterly, 1, 107-142.

Podsakoff, P.M., Mackenzie, S.B., Paine, J.B. ve Bachrach. D.G. (2000). Organizational citizenship behaviors: A critical review of the theoretical and empirical literature and suggestions for future research. Journal of Management, 26(3), 513-563.

Porter, L.W., Steers, R.M. ve Boulian, P.V. (1974). Organizational commitment, job satisfaction and turnover among psyciatric technicians. Journal of Applied Psychology, 59(5), 603-609.

Poyraz, K. ve Kama, B. (2008). Algılanan iş güvencesinin, iş tatmini, örgütsel bağllılı ve işten ayrılma niyeti üzerindeki etkilerinin incelenmesi, Süleyman Demirel Üniversitesi İktisadi ve İdari Bilimler Fakültesi Dergisi, 13(2), 143-164. 
Rifai, H.A. (2005). A test of the relationships among perceptions of justice, job satisfaction, affective commitment and organizational citizenship behavior. Gadjah Mada International Journal of Business, 7(2), 131-154.

Rothbaum, F., Weisz, J.R. ve Snyder, S.S. (1982). Changing the world and changing the self: A two-process model of perceived control. Journal of Personality and Social Psychology, 42(1), 5-37.

Rotter, J.B. (1954). Social Learning and Clinical Psycho$\log y$. New York, Prentice-Hall.

Rotter, J.B. (1966). Generalized expectancies for internal versus external control of reinforcements. Psychological Monographs, 80, 1-28.

Rotter, J.B. (1990). Internal versus external control of reinforcement: A case history of a variable. American Psychologist, 45, 489-493.

Salancik, G.R. (1977). Commitment is too easy. Organizational Dynamics, 6(1), 62-80.

Savaşır, I ve Şahin N.H. (1997). Bilişsel-Davranış̧̧ Terapilerde Değerlendirme: Sik Kullanilan Ölçekler. Ankara, Türk Psikologlar Derneği Yayınları.

Skarlicki, D. P. ve Folger, R. (1997). Retaliation in the workplace: The roles of distributive, procedural, and interactional justice. Journal of Applied Psycho$\log y, 82,434-443$.

Schnake, M. ve Dumler, M.P. (1993). The relationship between traditional leadership, super leadership and organizational citizenship behavior. Group and Organizational Management, 18(3), 352-366.

Shi, J., Lin, H., Wang, L. ve Wang, M. (2009). Linking the big five personality constructs to organizational justice, Social Behavior and Personality, 37(2), 209222.

Silvester, J., Anderson-Gough, F.M., Anderson, N.R. ve Mohamed, R. (2002). Locus of control, attributions and impression management in the selection interview. Journal of Occupational and Organizational Psychology, 75, 59-76.

Smith, C.A., Organ, D. ve Near, Y. (1983). Organizational citizenship behavior: Its nature and antecedents. Journal of Applied Psychology, 68(4), 653663.
Spector, P.E. (1988). Development of the work locus of control scale. Journal of Occupational Psychology, $61,335-340$.

Spector, P.E. ve Fox, S. (2003). Reducing subjectivity in the assessment of the job environment: development of the factual autonomy scale (FAS). Journal of Organizational Behavior, 24, 417-432.

Steers, R.M. (1977). Antecedents and outcomes of organizational commitment. Administrative Science Quarterly, 22(1), 46-56.

Strauser, D.R., Ketz, K. ve Keim, J. (2002). The relationship between self- efficacy, locus of control and work personality. Journal of Rehabilitation, 68, 20-26.

Sua'rez-Mendoza, M.J. and Zoghbi-Manrique-deLara, P. (2007). The impact of work alienation on organizational citizenship behavior in the Canary Islands. International Journal of Organizational Analysis, 15(1), 56-76.

Tatar, İ. (2006). İzlenim Yönetiminde Kendilik Algısı ve Stres, Yayımlanmamiş Yüksek Lisans Tezi, KHO Savunma Bilimleri Enstitüsü, Ankara.

Taylor, S.E., Peplau, A.L. ve Sears, D.O. (2006). Social Psychology (12th ed.). Englewood Cliffs, NJ: Prentice Hall.

Tepper, B.J. ve Taylor, E.C. (2003). Relationships among supervisors and subordinates procedural justice perceptions and organizational citizenship behaviors. Academy of Management Journal, 46(1), 97-105.

Thibaut, J. ve Walker, L. (1975). Procedural justice: A psychological analysis, Hillsdale, NJ: Lawrence Erlbaum Associates.

Thompson, H.B. ve Werner, J.M. (1997). The impact of role conflict / facilitation on core and discretionary behaviors: Testing a mediated model. Journal of Management, 23(4), 583-601.

Turnipseed, D. ve Murkison, G. (1996). Organizational citizenship behavior: An examination of influence the workplace. Leadership and Organizational Development Journal, 17, 42-47.

Turnipseed, D. ve Murkison, G. (2000). Good soldiers and their syndrome: Organizational citizenship behavior and the work environment, North American Journal of Psychology, 2(2), 1-16. 
Twenge, M.J., Zhang L. ve Im, C. (2004). It's beyond my control: A cross-temporal meta-analysis of increasing externality in locus of control, 1960-2002. Personality and Social Psychology Review, 8(3), 308-319.

Van Dyne, L., Graham, J.W. ve Dienesch, R.M. (1994). Organization citizenship behavior: Construct redefinition, measurement and validation. Academy of Management Journal, 37(4), 765-802.

Van Dyne, L., Vandewalle, D., Kostova, T., Latham, M.E. ve Cummings, L.L. (2000). Collevtivism, propensity to trust and self-esteem as predictors of organizational citizenship in a non-work setting, Journal of Organizational Behavior, 21, 3-23.

Van Scotter, J.R. ve Motowidlo, S.J. (1996). Evidence for two factors of contextual performance: job dedication and interpersonal facilitation. Journal of Applied Psychology, 81, 525-531.

Verquer, M.L., Beehr T.A. ve Wagner S.H. (2003). A meta-analysis of relations between person-organization fit and work attitudes, Journal of Vocational Behavior, 63(3), 473-489.

Vey, M.A. ve Campbell, J.P. (2004). In-role or extra-role organizational citizenship behavior: which are we measuring? Human Performance, 17(1), 119-135

Viswesvaran, C. ve Ones, D.S. (2003). Examining the construct of organizational justice. Journal of Business Ethics, 38, 193-203.

Wasti, A. (2000). Meyer ve Allen’in üç boyutlu örgütsel bağllilk ölçeğinin geçerlilik ve güvenilirlik analizi. 8. Ulusal Yönetim ve Organizasyon Kongresi: 401410.

Wiener, Y. (1982). Commitment in organizations: A normative view. The Academy of Management Review, 7(3), 418-428.
Williams, L.J. ve Anderson, S.E. (1991). Job satisfaction and organizational commitment as predictors of organizational citizenship and in-role behavior. Journal of Management, 17, 601-17.

Williams, S. ve Shiaw, W.T. (1999). Mood and organizational citizenship behavior: the effects of positive affect on employee OCB intentions. The Journal of Psychology, 133(6), 656-668.

Withey, M.J. ve Cooper, W.H. (1989). Predicting exit, voice, loyalty, and neglect. Administrative Science Quarterly, 34, 521-539.

Yağışan, N., Sünbül, A.M., Yücalan, Ö.B. (2007). Müzik bölümü öğrencilerinin benlik imgeleri ve denetim odaklarının incelenmesi. Selçuk Üniversitesi Sosyal Bilimler Enstitüsü Dergisi, 22, 243-262.

Yeşilyaprak, B. (2000). Eğitimde Rehberlik Hizmetleri. Ankara: Nobel Yayın Dağıtım.

Youn, D.H. (2007). The effects on job attitude of perception of justice in the HRM system, Japanese Journal of Administrative Science, 20(2), 185-201.

Zellars, K.L., Teper, B.J., Giacalone, R.A., Lockhart, D. ve Jurkiewicz, C.L. (2003). Justice and organizational citizenship: Interactive effects of impression management motives. Academy of Management Best Paper Proceedings: Seattle, 1-9.

Zhang, H. (2006). Antecedents and Consequences of Organizational Justice: An Investiation in China. Yayımlanmamış Doktora Tezi, McMaster University.

Zimmerman, R.D. (2008). Understanding the impact of personality traits on individuals' turnover decisions: A meta-analytic path model. Personnel Psychology, 61, 309-348. 